\title{
USE AND MANAGEMENT OF MEDICINAL PLANTS BY INDIGENOUS PEOPLE IN BOJI DIRMEJI DISTRICT, WESTERN ETHIOPIA
}

\author{
I. O. Duguma And M. A. Mesele* \\ (I.O.D.: Department of Biology, Boji Dirmeji Preparatory School, Ethiopia; \\ M.A.M.: Department of Biology, Adama Science and Technology \\ University, Ethiopia). \\ *Corresponding author's email: meseleadmassu@gmail.com
}

\begin{abstract}
Ethnobotanical study of traditional medicinal plants used by local people of Kondala Woreda was conducted from September 2016 to June 2017. The aim of the study was to collect, identify, describe, compile and document medicinal plant species used by the local people for the treatments of human and livestock ailments. A total of 49 informants from seven kebeles were selected. A total of 64 plant species were collected. Out of these, $78 \%$ of medicinal plant species were used as cure for human ailments, $12 \%$ of species for livestock and $10 \%$ of species for the treatment of both human and livestock. The most frequently used plant parts were leaves and roots. In the study area, there are threats to medicinal plants and firewood was ranked first by selected key informant followed by, agricultural expansion. Results indicated that Viciafaba is most effective in treating stomach ache while Cordia africana is used as multipurpose medicinal plants. Majority of the 64 medicinal plants that were cited by informants, $(57.8 \%)$ were used to treat a specific ailment. Thus, the community should conserve and manage these medicinal plant species before they become extinct.
\end{abstract}

Keywords: Ethnobotany, Indigenous knowledge, Informants, Traditional medicinal plants

\section{Introduction}

Most people from developing countries rely on traditional medicine. WHO (World Health Organization) estimated that about $80 \%$ of the developing nations entirely depend on traditional medicinal plants for health care (Abbink, 1995). Traditional medical practices for health care have been in existence for hundreds of years before the development of modern scientific medicine and are still in use today without much-documented evidence of their adverse effects (Okigbo \& Mmeka, 2006). According to Konno (2004), simple accessibility, efficacy on treatment and affordable cost in getting health services are the main reasons in preferring traditional medicine to modern medication. In Africa particularly traditional medicine has always existed and had been practiced since time immemorial. Traditional medicine as defined by the World Health Organization (WHO) and can be summarized as the sum total of all the knowledge, beliefs and practices that are used in diagnosis, prevention and elimination of physical, mental or social imbalance and rely exclusively on practical experiences and 
observation handed down from generation to generation (WHO, 1999).

The earliest mention of medicinal use of plants in Hindu culture is found in "Rigveda", which is said to have been written between 4500 - 1600 B.C. and is supposed to be the oldest repository of human knowledge. It is Ayurveda, the therapy involves the use of plant extract and their active constituents (Akerele, 1987). About 1500 plants are systematically used in indigenous system of medicine, like Ayurveda, Unani and Siddha. In all the developing countries, especially in the continent of Africa, the majority of the common people continue to rely heavily on the use of medicinal plants as their primary source of healthcare. About $70-80 \%$ of Africa's population relies on traditional medicine, for example, in Tanzania an estimated 30000 - 40000 traditional practitioners provide health service in comparison with 600 modern medical doctors (Hedberg et al., 1982). Also in Malawi, there were an estimated 17000 traditional practitioners and only 35 medical doctors (Anonymous, 1987). Indigenous knowledge of plants appeared when humans started and learned how to use plants (Posey, 1999). Over centuries, indigenous people have developed their own locality specific knowledge on plants use, management and conservation. The complex knowledge beliefs and practices are generally known as indigenous knowledge or traditional knowledge develops and changes with time and space, with change of resources and culture (Cotton, 1996). Indigenous knowledge is the main sources of all ethnobotanical investigations and is generally called as traditional ethnobotanical knowledge. However, the continuation of this knowledge is endangered because older people do not like to transfer knowledge to the young generation (Kargioglu et al., 2008).
Indigenous knowledge on usage of medicinal plants as folk remedies is getting lost through various reasons. According to Ensermu al. (1992), habitats and species are being lost rapidly because of environmental degradation, agricultural expansion, deforestation and urban development.

In Ethiopia, traditional medicine is faced with a problem of sustainability and continuity mainly due to the loss of taxa of medicinal plants (Ensermu et al., 1992; Zemede 2001). According to Abebe (2001), the diversity of plants in Ethiopia is on the process of being eroded mainly due to human-induced pressures. With the present ecological and socio-economical changes, the medicinal plants together with ethnobotanical knowledge are being lost forever (Tesfaye, 2003). Investigating medicinal plants and indigenous knowledge on sustainable use and management of plant resources, lack of conservation actions and activities is observed in Boji Dirmeji district, which is similar to other areas in Ethiopia. The current land use trend shows that the environment is facing problems of resource depletion and loss of indigenous knowledge like other areas of the country. Thus, concerted ethnobotanical research plays a vital role to draw information on plants and related indigenous knowledge for conservation and sustainable utilization. The current study is aimed to add some more information concerning indigenous knowledge on use, threat and management of medicinal plants by people of Boji Dirmeji district, Ethiopia.

\section{Experimental}

\section{Description of the study area}

The study was carried out in Boji Dirmeji district, Western Wollega Zone, Oromia Regional State, western Ethiopia. The study 
area lies between $8^{\circ} 43^{\prime} \mathrm{N}$ latitudes and $10^{\circ}$ 04' E longitude. The climatic region of the area described $66 \%$ of the sub-tropical and $34 \%$ of tropical. The study area is found within the altitudinal range of 1960 - $2058 \mathrm{~m}$ above sea level. Its distance from Addis Ababa is 475 $\mathrm{km}$ (CSA, 2012). The map of the study area is indicated in (Fig. 1).

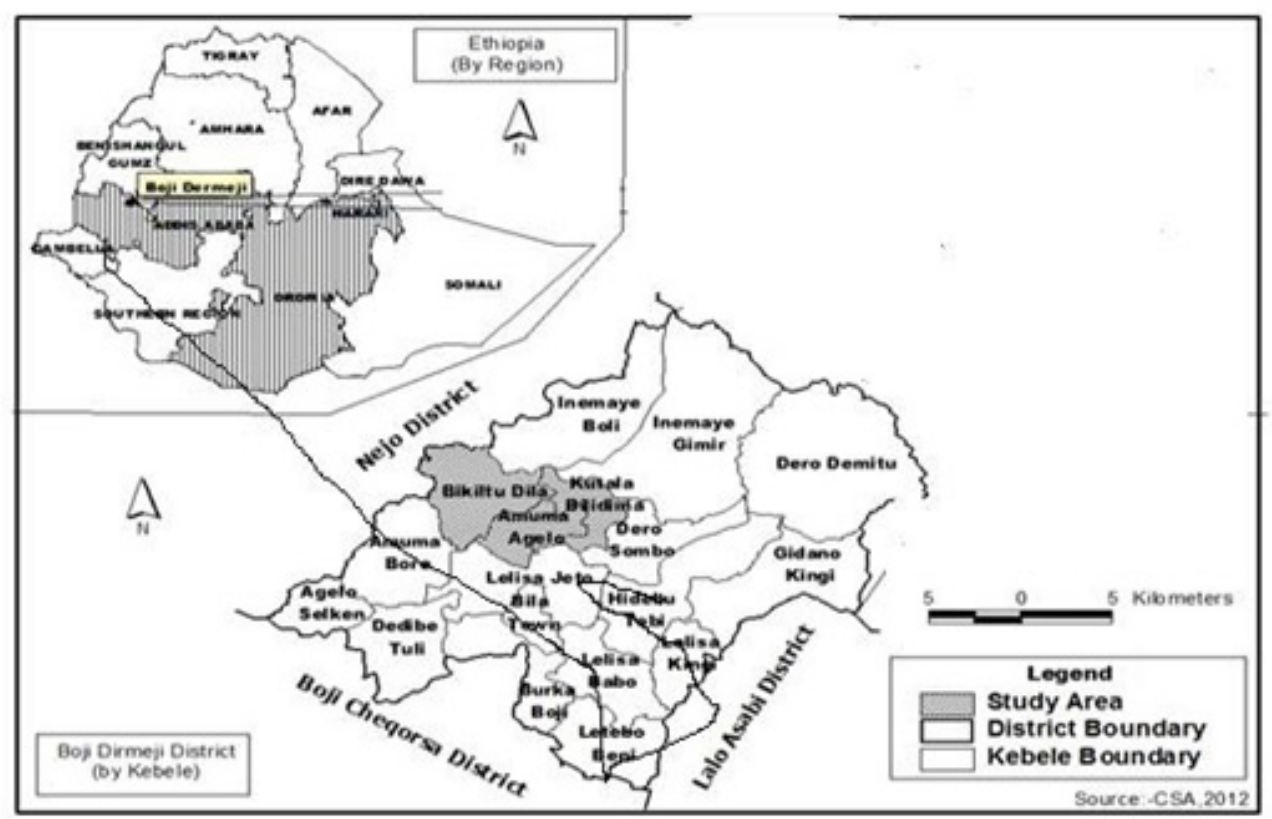

Fig. 1: Map of the study area. Source: (CSA, 2012).

\section{Methods}

\section{Field survey}

Survey of the study was carried out from September 2015 to November 2015. There were 19 kebeles in the district in the study area. From among these nine study sites were selected. These are Lelisa Babo, Hidabu Tobbi, Lelisa Kingi, Leta Bobine, Burka Boji, Lelisa Jeto, Amuma Agelo, Bikiltu Dilla and Kutala Bildima. The field survey was performed with the help of an authentic traditional herbalist. The study sites were divided using transect walk and based on etic and emic classification bases, the homogeneity of the vegetation was observed along with the density of medicinal plants in the area. To collect the medicinal plants 18 quadrats for wild and cultivated areas, and 18 quadrats for home gardens were made following (Martin, 1995 and Jha, 1997). At each study site, two plots with homogenous vegetation are resulting in 18 quadrats and 2 quadrats for home gardens in 9 kebeles resulting in 18 quadrats. From these plots, specimens were collected using a modified Whittaker NestedQuadrate Sampling method of Stohlgren et al. (1994). Trees were sampled in $20 \mathrm{~m}$ x $20 \mathrm{~m}$ plots, Shrubs $5 \mathrm{~m} \times 5 \mathrm{~m}$ and Herbs $2 \mathrm{~m} \times 2 \mathrm{~m}$ plot nested on the bigger plot, and $5 \mathrm{~m} \times 5 \mathrm{~m}$ quadrats for home gardens in a separate plot. 


\section{Focused Group Discussion}

From the nine study sites, 20 key informants were selected, 2 - 3 individuals from each site. Key informants were systematically selected based on the recommendation of knowledgeable elders, local authorities and developmental agents.

\section{Semi-structured interview}

Interviews and discussions were held based on a checklist of questions prepared beforehand in English translated to the local language. During an interview, the local name of medicinal plant part used, disease treated, dosage, methods of preparation, and adverse effects were recorded. A total of 63 informants (41 males and 22 females), comprising of seven individuals from each study site aged between 31 - 105 were randomly selected from 9 kebeles. The simple random technique was used for the sampling of the interviewees. Specimen Collection and Identification

Medicinal plants and other associated plants were collected, some in the wet season $(75 \%)$ and little in the dry season (25\%) from wild and cultivated areas guided by local healers, indigenous herbalists and knowledgeable elders. Based on ethnobotanical information provided by informants, the plants were collected, numbered, pressed, and dried for identification. Medicinal plant species identification was carried out at Addis Ababa University herbarium.

\section{Data sources}

\section{Informant consensus}

In order to evaluate the reliability of information recorded during the interview, informants were contacted at least two times for the same ideas and the validity of the information was proved and recorded. Only the relevant ones were taken into account and statistically analyzed (Alexiades, 1996).

\section{Data Analysis}

Preference ranking and paired comparison were computed to assess the degree of effectiveness of certain medicinal plants against some human ailments, spider poison and bat poison respectively. Descriptive statistical analysis and Pearson correlation coefficient were used to analyze the relationship between knowledge distributions by age of respondents.

\section{Results}

In this study 124 medicinal plants were collected, identified and documented in the study area for further use and study. Most of the medicinal plants about $74.2 \%$ (92), were harvested from wild; among these herbaceous species were the leading in treating ailments. About 25.8\% (32) were harvested from home gardens.The most widely used medicinal plants in the study area were in the form of herbs. They were about 43 (34\%), trees were $37(29 \%)$ and shrubs were $10(20 \%)$. Plant parts such as roots, leaves, stems, fruits, etc. identified for treatment of different diseases and reported by indigenous people in the study area is in (Table 1). 
TABLE 1

Plant parts used in the preparation of traditional medicine (reported by respondents in Boji Dirmeji district).

\begin{tabular}{ll|l}
\hline $\begin{array}{l}\text { Parts used } \\
\text { Number of species total } \\
\text { \% of the total }\end{array}$ & \multicolumn{2}{c}{$\%$ of total } \\
\hline Leaf only & 50 & $40 \%$ \\
Root only & 35 & $28 \%$ \\
Stem only & 11 & $9 \%$ \\
Seed only & 11 & $9 \%$ \\
Latex only & 3 & $4 \%$ \\
Fruit only & 5 & $2 \%$ \\
Whole plant & 3 & $6 \%$ \\
Two and more parts combined & 8 & \multicolumn{2}{c}{$100 \%$} \\
\multicolumn{1}{c}{ Total } & &
\end{tabular}

The methods used for traditional medicinal plants preparation by the local healers included crushing, powdered vegetable drug, boiling and inhaling its smoke, chewing, infusion, crushing and smoked, etc. 
TABLE 2

Medicinal plant species used to treat human and animal diseases in Boji Dirmeji district.

\begin{tabular}{llll}
\hline $\begin{array}{l}\text { Number of } \\
\text { species }\end{array}$ & $\begin{array}{l}\text { Treatment } \\
\text { for Human beings }\end{array}$ & Livestock & Total \\
\hline
\end{tabular}

\begin{tabular}{|c|c|c|c|c|}
\hline Acanthaceae & 1 & & & 1 \\
\hline Alliaceae & & 1 & & 1 \\
\hline Aloaceae & 1 & & & 1 \\
\hline Aizoaceae & 1 & & & 1 \\
\hline Araceae & & 1 & 1 & 2 \\
\hline Asteraceae & 4 & & 4 & 8 \\
\hline Asclepiadaceae & & & 1 & 1 \\
\hline Amaranthaceae & 1 & & & 1 \\
\hline Anacardiaceae & 2 & & & 2 \\
\hline Apocynanceae & 1 & & & 1 \\
\hline Bignoniaceae & 1 & & & 1 \\
\hline Boraginaceae & 3 & & & 3 \\
\hline Brassicaceae & 1 & & & 1 \\
\hline Cannaceae & & & 1 & 1 \\
\hline Cancelleceae & & & 1 & 1 \\
\hline Caricaceae & 1 & & & 1 \\
\hline Capparidaceae & & & 1 & 1 \\
\hline Celastraceae & 1 & & 1 & 2 \\
\hline Combretaceae & 1 & 2 & 1 & 4 \\
\hline Colchicaceae & 1 & & & 1 \\
\hline Crassulaceae & & 1 & 1 & 2 \\
\hline Cucurbitaceae & 4 & & 1 & 5 \\
\hline Dracaenaceae & & 1 & & 1 \\
\hline Euphorbiaceae & 2 & & 2 & 4 \\
\hline Fabaceae & 5 & 1 & 4 & 10 \\
\hline Flacourtiaceae & 1 & & & 1 \\
\hline
\end{tabular}


Geraniaceae

Lamiaceae

Lauraceae

Liliaceae

Linaceae

Lobeliaceae

Loganiaceae

Loranthaceae

Malvaceae

Meliaceae

Melianthaceae

Mensipermaceae

Moraceae

Myrsinaceae

Myrtaceae

Nyctagnaceae

Phytolaccaceae

Piperaceae

Plantaginaceae

Poaceae

Podocarpaceae

Polygonaceae

Polygalaceae

Ranunculaceae

Resedaceae

Rhamnaceae

Ribiaceae

Rosaceae

Rubiaceae

Rutaceae

Sapindaceae

Simaroubaceae
1

3

1

1

1

1

1

2

1

1

1

1

5

1

1

4

1

2

1

2

1

5

1

1

1

2

2

1

2

1

1

2

2

6

1

1

1

1

1

4

1

2

1

$\begin{array}{ll}1 & 1 \\ 2 & 2\end{array}$

1

2

1

3

1

2

2

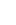

1

1 


\begin{tabular}{|c|c|c|c|c|}
\hline Solanaceae & 3 & & 1 & 4 \\
\hline Salicaceae & & 1 & & 1 \\
\hline Tiliaceae & & 1 & & 1 \\
\hline Urticaceae & 2 & & & 2 \\
\hline Verbenaceae & & & 1 & 1 \\
\hline Zinziberaceae & & & 1 & 1 \\
\hline Total & 74 & 18 & 32 & 124 \\
\hline
\end{tabular}

The result of the study showed preference of Clematis simensis to Hygrophilia auriculata in treating spider poison (Table 3).

TABLE 3

Preference ranking of medicinal plants used to treat spider poison.

\begin{tabular}{|c|c|c|c|c|c|c|c|c|c|c|}
\hline \multirow[b]{2}{*}{ Medicinal plants } & \multicolumn{4}{|c|}{ Respondents A-H } & \multirow[b]{2}{*}{$\mathrm{E}$} & \multirow[b]{2}{*}{$\mathrm{F}$} & \multirow[b]{2}{*}{ G } & \multirow[b]{2}{*}{$\mathrm{H}$} & \multirow[b]{2}{*}{ Total } & \multirow[b]{2}{*}{ Rank } \\
\hline & A & $\mathrm{B}$ & $\mathrm{C}$ & $\mathrm{D}$ & & & & & & \\
\hline Corida africana & 5 & 3 & 1 & 2 & 1 & 1 & 1 & 1 & 15 & 5 th \\
\hline Rumex nepalensis & 2 & 5 & 1 & 3 & 3 & 3 & 2 & 3 & 22 & $3 \mathrm{rd}$ \\
\hline Clematis simensis & 6 & 6 & 5 & 6 & 4 & 6 & 5 & 6 & 44 & $1 \mathrm{st}$ \\
\hline Rumex Abyssinicus & 3 & 1 & 1 & 2 & 4 & 1 & 1 & 1 & 14 & 6 th \\
\hline Hygrophilia & 4 & 3 & 6 & 3 & 6 & 3 & 6 & 5 & 36 & $2 \mathrm{nd}$ \\
\hline \multicolumn{11}{|l|}{ auriculata } \\
\hline Geranium arabicum & 5 & 1 & 3 & 2 & 1 & 1 & 2 & 4 & 19 & 4 th \\
\hline
\end{tabular}

A paired comparison rank made among some medicinal plants treating bat poison revealed that Achyranthes aspera was most important plant species, followed by Sporobolus indicus (Table 4). 
TABLE 4

Paired comparison of medicinal plants used to treat bat poison.

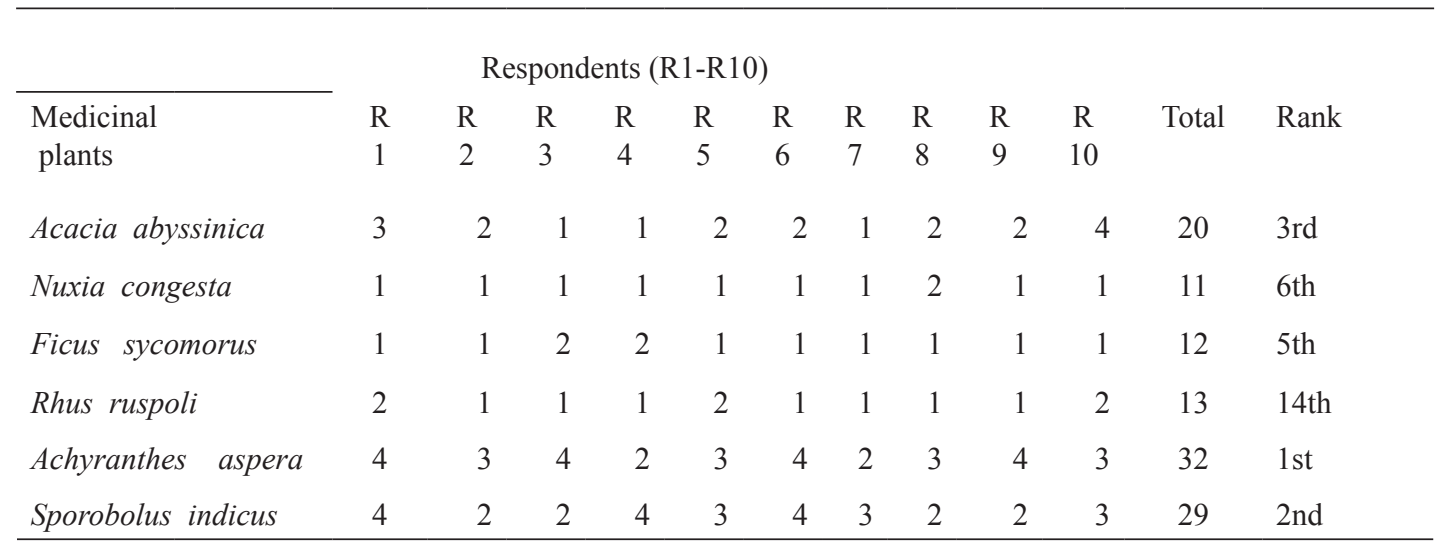

(1=Least; 2 = Good; $3=$ very good; 4= Excellent. $)$

\section{Discussion}

In this study, 124 medicinal plant species collected and identified in herbarium belong to 64 families documented in the study area during the study period. 92 species were collected from wild natural forest. The plants were distributed among 76 genera and 37 families. The family Fabaceae was represented the most abundant followed by Asteraceae. Regarding life form diversity, herbs stood first with 44 species and shrubs with 36 species. The families with the highest number of species in treating health problems in a human were Fabaceae and Myrtaceae each contributing five species and Combretaceae (two species) in livestock. In both human and livestock treatments, Asteraceae and Fabaceae contributed four species each. In the current study, 92 different types of health problems 74 in humans and 18 in livestock, 32 species common to both human and livestock were identified. The result of the study also indicated that the highest proportions of medicinal plants were used in treating stomach ache in human and blackleg in live stocks respectively.

There is a great difference between home gardens practiced by rural and urban people both in size of the land used as home garden and diversity of the medicinal plants to be cultivated. In-home garden survey of nine rural kebeles, 34 useful plant species was noted. Eighteen home gardens, two plots for each kebele were used. The plants were distributed among 27 families and 34 genera. The dominant family in terms of species composition was Fabaceae. Out of the 34 home gardens, 18 were herbs and 16 were shrubs. The study showed that 10 medicinal plants were used for their food values. The result of the study agrees with home garden utility, with the work of Giday (2000).

A medicinal plant that received the highest informant consensus, Crepis ruepppe was not frequently distributed in the study sites. This could be due to the fact that it was overused 
and disappeared. This may be because of the destruction of its habitat due to deforestation. Less medicinal knowledge in relation to young age might be attributed to the fact that traditional knowledge is built with years of experience (Hill, 2003). This may be due to the transfer of knowledge of medicinal plans following vertical transfer to the most selected family members orally with great secrete from generation to generation and transferring the knowledge of medicinal plants is usually at old age.

The medicinal plant species in the district are also used as remedies in other parts of Ethiopia and Africa. The finding has revealed that the majority of the traditional healers in the study area rely on traditional knowledge, practices and locally available materials (Abbink, 1995). Medicinal plants cure and prevent different diseases such as spider poison, wound, bat poison, acute diarrhea and vomiting, and rabies. Most of the medicinal plants were collected from the wild 92 (73\%) and others from home gardens.

Medicinal plants in the study area were similar to those found in different parts of the country. Among the 126 medicinal plants species, 112 species $(89 \%)$ were also found in other parts of the country. Hence, from this point of view, the local people over a wide area in Ethiopia showed the tendency to use the same medicinal plants and this could be an indicator for the genuine therapeutic value of these medicinal plants as well as indigenous knowledge on medicinal plants. The finding showed that most medicinal values $(73 \%)$ were from the wild, while few of medicinal plants $(13 \%)$ were in cultivated areas. This is in line with the works of Zemede (2001) which stated that there was less practice of cultivating medicinal plants near residential areas. From the interview made with informants and its analysis, it was noted that very few informants have the interest to cultivate some selected medicinal plants and were limited by land scarcity and financial resources. Almost all informants prefer the collection of medicinal plants from the wild. This finding was in line with the works of Debela (2004). The presence of more medicinal herbs in the vegetation of the study area can be an indicator of the fact that there might be less exposure of herbs to various threats as compared with trees and shrubs. It is true that herbs can grow everywhere (roadside home garden, farmland and wild). This finding is in line with the works of Giday (2000) and Endalu (2007).

During group discussion sessions most informants reported that they preserve the plant material that they could not find in the dry or rainy season by various ways like pounding and saving the powder for later uses. The result of informant consensus showed that some medicinal plants and their utilization were more popular than others. From the medicinal plants cited by seven or more informants (45\%) or from more informant consensus, Crepis rueppe and Gloriosa superba $47(75 \%)$ were indicated relatively by highest number of in formants than Geranium arabicum 45(71\%) The finding of Debela (2001) indicated that diseases that are frequent in the study areas have higher informants' consensus.

This study confirms that before the use of medicinal plants for treatments it is prepared in different forms. For instance grinding, crushing, and pounding, but crushing, grinding and homogenizing in water takes the lead. This work is in agreement with the findings of Kebu et al. 2004. A similar study showed that most remedies $73 \%$ were prepared from single plant and preparation from combined plant species was about (23\%). This result 
was in agreement with the findings of Dawit (1996), Etana (2007) and Debela (2001), in which the single plant preparations were reported to be high. The part of medicinal plant which is highly used for the preparation of the remedies was using leaves and roots. The highest condition on preparation was fresh $62 \%$ and dry $25 \%$. Most of the medicinal plants were administered orally in which oral administration accounts about 63\%,external use 36 (29\%) and dermal or skin 29\%.

The preference ranking and paired comparison, ranking of medicinal plants on their efficiency indicated that the indigenous people through life experience have identified the best medicinal plants that could be used for the same problem. Conservation was poor due to agricultural expansion in the area and this agrees with works of Giday (2001).

\section{Conclusion and Recommendations}

There was large a number of valuable resources, practices and knowledge of medicinal plants which can solve problems regarding the shortage of drugs at rural. The abundance of medicinal plants is declining because of anthropogenic and natural factors. The main threats to these resources emanate from agricultural expansion, overgrazing, termite mound formation, wood extraction and recurrent drought. Knowledge of medicinal plants use is probably declining through failure to transfer from the elderly to the young due to the fading interest of the young. Traditional medicine was preferred to modern medical systems in treating spider poison, bat poison, rabies, anthrax, and abdominal disorders.

Modernization and modification of culture and increasing business activities in the area have played an immense role in changing the attitude of the younger generation to ignore the use of traditional knowledge. In general, medicinal plants with higher informants' consensus need to be seriously considered for further ethnopharmacological studies since they are species widely used by many people and utilized for a long time. Generally, religious, spiritual and cultural related practices played a significant role in the conservation of resources and medicinal plants in the area.

Genetic resources contained in medicinal plants are being lost. The irretrievable loss of this biodiversity is a result of mismanagement and degradation of ecosystem Therefore, based on the results, of the current findings; the following points have been suggested:

- Build national scientific capacities and capabilities to explore, collect, conserve, characterize evaluate and utilize the phytomedicine of the area.

- Recognize, foster, and augment the indigenous knowledge and methods relevant to the conservation, development and sustainable use of herbal medicine, and promote and encourage the development and practice of using the medicine in modern ways.

- Indigenous people of the study area should be involved in the conservation and management of plant resources and their indigenous knowledge in their locality.

- Train the local people, on resource use-value, management and conservation at kebele or district level by agricultural experts or development agents, in order to facilitate an integration to conserve and use the medicinal plants on a sustainable basis.

- Recognitions and intellectual property (patent) rights of the traditional healers should be enhanced either 
through certification or through organizing them at community or district levels.

- In-situ and ex-situ conservation activities should be practiced in the district through training of model farmers to ensure the sustainable use of medicinal plants.

\section{Acknowledgements}

We would like to thank Adama Science and Technology University for financial support. We would also like to thank the Biology Department for the facilities and support given during the entire study period.

\section{Conflict of Interest}

There is no conflict of interest. This is our own original research work carried out in Boji Dirmeji district, Ethiopia.

\section{References}

ABbinK, J. (1995) Medicinal and ritual plants of the Ethiopian southwest: An Account of recent Research. Indigenous knowledge and Development Monitor 3 (2), 6 - 9.

Abebe, D. (2004) Biodiversity conservation of medicinal plants: problem and prospects. In: Conservation and sustainable use of medicinal plants in Ethiopia. Proceeding of the National workshop on Biodiversity conservation and sustainable use of medicinal plants in Ethiopia.

AKERELE, O. (1987) The best of both worlds: bringing traditional medicine up to date. Society of Science Medicine 24, 172 - 183.

Alexiades, M. N. (1996) Collecting Ethnobotanical data. In: Alexiades, M. N. and Sheldon, J. W. (eds), selected Guideline for Ethnobotanical Research: A field manual. The New York Botanical Garden, Bronx, New York, USA. PP, 35 - 106.
ANONYMOUS (1987) Statement of Development Policies 1987 - 1996. Republic of Malawi. Zomba, 1987.

Cotton, C. M. (1996) Ethnobotany: Principles and Applications, John Wiley and sons Ltd. chichester, England. 345pp.

CENTRAL STATISTICAL AGENCY (2012) Map of Boji Dirmeji District with its Kebeles, 2012.

Dawit, A. (1996) Traditional medicine in Ethiopia. The attempts being made to promote it for effective and better Utilization. SNET, 62 70 .

Debela, H. (2001) Use and Management of Traditional Medicinal plants by Indigenous people of Boosat Woreda, Wolenchiti area: An Ethno botanical Approach. M.Sc.

Thesis. Addis Ababa University.

Debela, H. (2004). Zemede Asfaw and Ensermu Kelbessa. Use and Management of Ethnoverinary Medicinal plants of Indigenous People in 'Boosat', Wolenchiti Area.. Journal of. Biological. Science 3 (2), 111 - 134.

Endalu, A. (2007) Use and Management of Medicinal plants by Indigenous people of Ejaji Area (Chelya district) West shoe. An Ethnobotanical approach. M.Sc. Thesis. Addis Ababa, Ethiopia.

Ensermu, K., Sebsebe, D., Zerinun, W., et al., (2000) Threatened Endemic plants of Ethiopia .In: Edwards,s.and Zemede Asfaw (eds.). Plants used in African traditional Medicine as practiced in Ethiopia and Uganda, $34-56$ Botany NAPREC, Monograpgh series No, 2. Addis Ababa University, Ethiopia.

Etana, T. (2007) Use and conservation of Traditional Medicinal Plants by Indigenous people in Gimbi Woreda, Western Wollega. M.Sc. Thesis. Addis Ababa, Ethiopia. 
GidaY, M. (2001) An Ethnobotanical study of Medicinal plants used by the Zay people in Ethiopia. Skrift Series 3, $82-88$.

Hedberg, O. (2006) Polygonaceae. In: Edwards S Mesfin Tadesse Sebsebe Demissew and Hedberg I (eds.). Flora of Ethiopia and Eritrea. The National Herbarium. Addis Ababa University Addis Ababa. Ethiopia and Uppsala 2 (1), 341 - 334.

Hedberg, O., Posany, J. M., Keto, E., et al., (1982). Inventory of Plants used in traditional medicine in Tanzania. Part III. Plants of the families' papilionaceavitaceae. J. Ethnophar. 9, 237 - 260 .

HiLl, D. M. (2003) Traditional medicine in contemporary contexts. protecting and respecting indigenous knowledge and medicine. National Aborginal Health Organization www.naho.cal English/pdf/research.Tradition. Accessed on July 25, 2016.

JHAN, P. K. (1997) Environment plant resources and quantities estimation methods for vegetation analysis. In: Shrestha, K.K., Jha, P.K., Shengi, P., Rastogi, A., Rajibandary, S., Joshi, M. (eds). Ethnobotany for conservation and community Development. Ethnobotanical society of Nepal (ESO), Nepal.

Kargioglu, M. Cenkci, S. Serteser, A., et al., (2008) An Ethno botanical survey of Inner- West Anatolia, Turkey. Human Ecology 36, 763 778.

Kebu, B. Ensermu, K. \& Zenede, A. (2004) Indigenous medicinal plant utilization, management and treats in Fentale area, Eastern Shewa, Ethiopia. Ethiopi.J. Biol. Sci 3 (1), 34 - 60.
Konno, B. (2004) Integration of traditional medicine with modern medicine. EHNRI, Addis Ababa. PP, 2 -10.

Martin, G. J. (1995) Ethnobotany. A method Manual. Chapman and Hall, London, 64 - 272pp.

Okigbo, R. N. \& MmeкA, E. C. (2006) An appraisal of phyto-medicine in Africa. Science Technology Journal 6 (2), 81 - 96.

Posey, D. (1999) Ethnobotany: Its implication and application. In: Posey D. A. and Overol W. L. (eds.). Proceedings of the First International Congress of Ethino-biology 1999.

Stohlogren, T. J., Falkner, M. B. \& Shell, L. D. (1994) Nested Vegetation Sampling Method. In: Vegetation, 117, 113 - 121. Kluwer Academic Publishers, Belgium.

Tesfaye, H. (2003) An Ethnobotanical Study of Medicinal Plants Used by Local People in the Lowlands of Konta Special Woreda, SNNPRs, Ethiopia. MSc. Thesis Presented to the School of Graduate Studies, Addis Ababa University, Addis Ababa, 111pp.

WHO (1999) Monographs on selected medicinal plants. World Health Organization, Geneva. 1999: $1 \& 2$.

Zemede, A. (2001) The role of home gardens in production and conservation of medicinal plants. In: conservation and sustainable Use of Medicinal plants in Ethiopia, Proceeding of the National Workshop on Biodiversity and Sustainable use of Medicinal Plants in Ethiopia, 28 April - 01 May 1998, (Medhin, Z. and Abebe, D. eds.). IBCR, Addis Ababa, 74 -93 pp.

Received 08 Mar 19; revised 29 Jul 19. 